\title{
The Believer and the Modern Study of the Bible
}

In memory of Belda and Marcel Lindenbaum

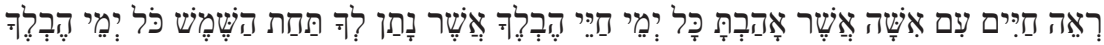

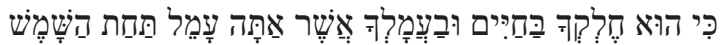

קהלת ט, ט

Enjoy happiness with a woman you love all the fleeting days of life that have been granted to you under the sun all your fleeting days.

For that alone is what you can get out of life and out of the means you acquire under the sun.

Ecclesiastes 9:9 

The editors are grateful to Targum Shlishi, a Raquel and Aryeh Rubin
FARGUM Foundation for making the open-access publication of this book
SHLISHI possible.

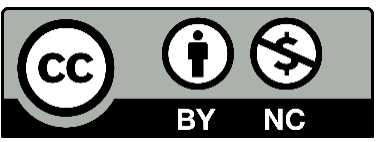

This book is subject to a CC-BY-NC license. To view a copy of this license, visit https://creativecommons.org/licenses/by-nc/4.0/. Other than as provided by these licenses, no part of this book may be reproduced, transmitted, or displayed by any electronic or mechanical means without permission from the publisher or as permitted by law.

The open access publication of this volume is made possible by:
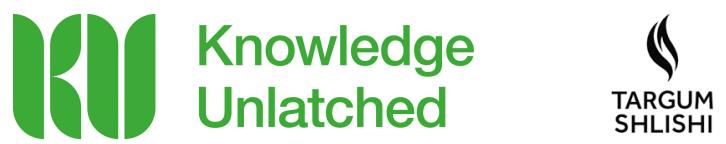


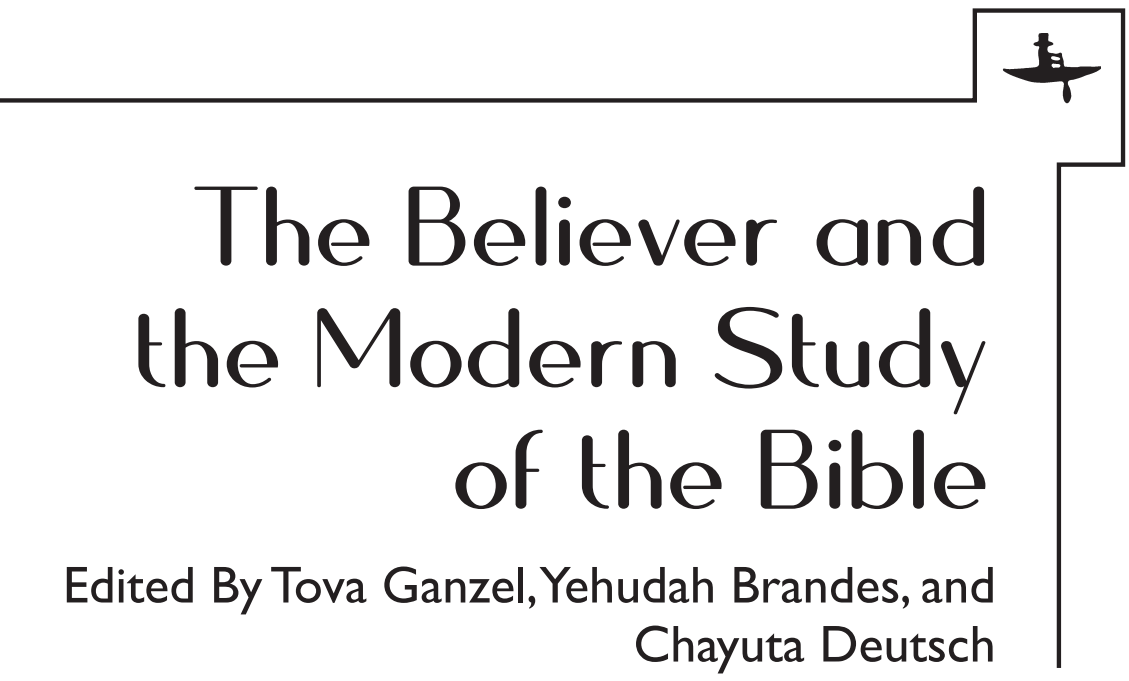




\section{Library of Congress Cataloging-in-Publication Data}

Names: Ganzel, Tova, editor. | Brandes, Yehudah, editor. | Deutsch, Chayuta, editor.

Title: The Believer and the modern study of the Bible / edited by Tova Ganzel, Yehudah Brandes, and Chayuta Deutsch.

Other titles: Be-'ene 'Elohim ve-'adam English

Description: Boston : Academic Studies Press, 2019.

Identifiers: LCCN 2018055402 (print) | LCCN 2018056609 (ebook) | ISBN 9781618119520 (ebook) | ISBN 9781618119513 (hardcover)

Subjects: LCSH: Bible. Old Testament-Criticism, interpretation, etc. | Bible. Old Testament-Criticism, Redaction. | Bible. Old TestamentCommentaries. | Tradition (Judaism) | Faith (Judaism)

Classification: LCC BS1188 (ebook) | LCC BS1188. B4413 2019 (print) | DDC 221.601-dc23

LC record available at https://lccn.loc.gov/2018055402

(C) Academic Studies Press, 2019

ISBN 9781618119513 (hardcover)

ISBN 9781618119520 (ebook)

Book design by Kryon Publishing Services (P) Ltd.

www.kryonpublishing.com

On the cover: "Tiferet," by David Rakia (1928-2012). Oil on canvas.

Courtesy of Karin Rakia Simantov

\section{Published by Academic Studies Press}

28 Montfern Avenue

Brighton, MA 02135, USA

press@academicstudiespress.com

www.academicstudiespress.com 